\title{
Enkapsüle Edilmiş ve Serbest Formda Probiyotik Lactobacillus acidophilus ATCC 4356 Suşunun Dondurma Depolama Periyodunda Stabilitesinin Incelenmesi
}

\section{Sedat SEDEFOĞLU1'D, Fatih ORTAKCl' ${ }^{2}$, Selahattin SERT ${ }^{3}$ D \\ 'Şen Piliç Mesleki ve Teknik Anadolu Lisesi, Sakarya, Türkiye ${ }^{2}$ Abdullah Gül Üniversitesi, Yaşam ve Doğa Bilimleri Fakültesi, Biyomühendislik Bölümü, Kayseri, Türkiye \\ ${ }^{3}$ Atatürk Üniversitesi, Ziraat Fakültesi, Gıda Mühendisliği Bölümü, Erzurum, Türkiye}

Geliş Tarihi/Received: 15.04.2021

Kabul Tarihi/Accepted: 05.11.2021

Sorumlu Yazar/Corresponding Author: Sedat SEDEFOĞLU

E-mail: sedat.sedefoglu@ogr.atauni. edu.tr

Cite this article as: Sedefoğlu, S., Ortakcı, F., \& Sert, S. (2022) Evaluation of the Stability of Sncapsulated and Free Probiotic Lactobacillus acidophilus ATCC 4356 Strain During Ice Cream Storage. Atatürk University Journal of Agricultural Faculty, 53(1):14-23.

\section{Evaluation of the Stability of Encapsulated and Free Probiotic Lactobacillus acidophilus ATCC 4356 Strain During ice Cream Storage}

öz

Bu çalışmada probiyotik Lb. acidophilus ATCC 4356 (ATCC 4356) suşu, ekstrüzyon yöntemi ile aljinat kullanılarak kapsüllenmiştir. Bu enkapsüle ve serbest formdaki ATCC 4356 dondurmaya ilave edilerek $-18^{\circ} \mathrm{C}$ 'de 3 ay süre ile depolanmıştır. Depolamanın 0, 30 ve 90. günlerinde alınan örneklerde, ATCC 4356'nin canlılığını sürdürebilme yeteneği karşılaştırmalı olarak ortaya konulmuştur. Araştırma sonuçlarına göre, dondurmaya ilave edilen serbest ve enkapsüle ATCC $4356^{\prime}$ nın, $-18^{\circ} \mathrm{C}$ 'de 3 aylık depolama süresinin sonunda canlılıklarını korudukları, buna karşıık sayılarındaki azalışın istatistiki olarak farklı düzeyde olmadıkları tespit edilmiştir $(P>$,05). Bununla birlikte, dondurmaların 90 günlük depolama periyodu boyunca, serbest ve enkapsüle $L b$. acidophilus ATCC 4356 sayılarının $10^{7}$ kob/g'ın altına düşmemiş olması, son üründe probiyotiklerin arzu edilen düzeyde canlılığını koruduğunu göstermiştir. Dolayısıyla bakterinin terapotik etkiler gösterebilme açısından dondurmanın uygun bir gıda olarak kullanılabileceği düşünülmektedir. Serbest ve enkapsüle dondurmalara ait duyusal analiz sonuçlarında ise enkapsülasyonun dondurmanın yapı ve tekstüründe önemli seviyede etkiye yol açtığı $(P<, 05)$ ve genel kabul düzeyi olarak serbest ve enkapsüle dondurmalardaki farkın önemli seviyede olduğu gözlemlenmiştir $(P<, 05)$. Bununla birlikte renk, görünüş, tat ve koku kriterleri bakımından serbest ve enkapsüle dondurmalardaki farkın önemsiz seviyede olduğu belirlenmiştir $(P>, 05)$.

Anahtar Kelimeler: Enkapsülasyon, ekstrüzyon metodu, Lactobacillus acidophilus, dondurma, probiyotik

\section{ABSTRACT}

In this study, the probiotic Lactobacillus acidophilus ATCC 4356 (ATCC 4356) strain was encapsulated using alginate by extrusion method. This encapsulated and free form ATCC 4356 was added to ice cream and stored at $-18^{\circ} \mathrm{C}$ for 3 months. In the samples taken on the 0,30 , and 90 th days of storage, the ability of ATCC 4356 to survive was demonstrated comparatively. According to the results of the research, it was determined that free and encapsulated ATCC 4356 added to ice cream preserved its vitality after 3 months of storage at $-18^{\circ} \mathrm{C}$ but the decrease in their numbers was not at a statistically different level $(P>$.05). However, the fact that the free and encapsulated Lb. acidophilus ATCC 4356 numbers did not fall below $10^{7} \mathrm{cfu} / \mathrm{g}$ during the 90 -day storage period of the ice creams showed that the probiotics maintained their viability at the desired level in the final product. Therefore, it is thought that ice cream can be used as a suitable food in terms of the bacteria showing therapeutic effects. According to the sensory analysis results of free and encapsulated probiotic containing ice creams, the encapsulation caused significant reductions on structure and texture $(P<.05)$. Also, overall acceptance rate of encapsulted probiotic containing ice creams was significantly lower than free cells containing product $(P<.05)$. However, it was 
determined that the difference between free and encapsulated ice creams in terms of color, appearance, taste, and odor criteria was insignificant $(P>$.05).

Keywords: Encapsulation, extrusion method, Lactobacillus acidophilus, ice cream, probiotic

\section{Giriş}

Probiyotikler, Dünya Sağlık Örgütü tarafından (DSÖ, WHO), “yeterli miktarda verildiğinde konakta sağlığa yararlı etki yapan canlı mikroorganizmalar" olarak tanımlanmaktadır (FAO/WHO, 2002). Günümüzde birçok kaynaktan probiyotik bakterileri almaktayız. Bunların başlıcaları fermente besin maddeleri (fermente süt, yoğurt, peynir, fermente sebzeler, turşu vs.), insan ağız florası, intestinal orijinli ve paketlenmiş veya kapsüllenmiş tedavi edici ürünlerdir (Özden, 2008). Probiyotiklerin konakçıdaki etkileri, bağırsak pH'sını değiştirmek, antimikrobiyal ürünler üreterek patojen bakterilerin üremesini inhibe etmek, bağlanma bölgeleri ve besin maddeleri için patojen bakterilerle yarışmak, immunmodulatör hücreleri uyarmak olarak sayılabilir (Kaleli, 2007). Bununla birlikte probiyotik mikroorganizmaların faydalı etki gösterebilmeleri için, $10^{6}-10^{7} \mathrm{kob} / \mathrm{ml}$ veya daha fazla sayıda vücuda alınmaları ve içinde bulundukları gıdaların üretimi ve raf ömrü süresince canlı kalabilmeleri gerekmektedir (Ünal ve Erginkaya, 2010). Ayrıca probiyotik olarak gıdalarda kullanılacak bir mikroorganizma patojen olmamalı, insan kaynaklı olmalı, stabil olmalı, mide asidi ve safra tuzuna karşı direnç göstermeli, bağırsak yüzeyine tutunabilmeli ve gastrointestinal sistemde az da olsa yaşamını devam ettirebilmeli, antimikrobiyal bileşikler üretebilmeli, bazı enzim ve vitamin üretimi sayesinde metabolik etki gösterebilmeli ve bağışıklık sistemini uyarmalıdır (Bilginer ve Çetin, 2019).

İstenen probiyotik özelliklere sahip ve klinik olarak etkisi kanıtlanmış suşlar genellikle Lactobacillus ve Bifidobacterium cinslerine ait türlerdir (Karthikeyan ve ark., 2014). Lb. acidophilus probiyotik bakteri olarak gıda formülasyonlarında oldukça yaygın olarak kullanılan Lactobacillus türlerinden biridir (Sanders \& Klaenhammer, 2001). Karbonhidrat metabolizmaları sonucunda temel ürün olarak laktik asit oluşturan, çoğunlukla zorunlu homofermentatif bir bakteridir (Donkor, 2007). Insan ve hayvanlarda doğal gastrointestinal sistem içerisinde, insan ağız florası ve vajinada ve kefir gibi bazı geleneksel fermente süt ürünlerinde yaygın olarak bulunur. Optimum gelişme pH aralığı 5.5-6.0'dır. Bundan dolayı birçok $L b$. acidophilus suşunun düşük $\mathrm{pH}$ nedeniyle fermente süt içinde gelişimlerinin iyi olmadığı söylenebilir (Donkor, 2007).

Probiyotik mikroorganizmaların kullanımı özellikle süt ve süt ürünleri olmak üzere çeşitli fermente gıda ürünlerinde oldukça yaygındır (Granato ve ark., 2010). Bununla birlikte genişleyen probiyotik ürün sınıfı içinde çok az sayıda araştırmacı ve süt işletmesi, yüksek sayıda probiyotik kültür içeren dondurma çeşitlerinin üretimi konusunda çalışmışlardır.

Dondurma, besin değerinin yüksek olması ve sindiriminin kolaylığı yanında, sevilen tat ve aroması ile ferahlatıcı niteliği sayesinde tüketimi oldukça fazla olan ve toplumun hemen her kesimi tarafından sevilerek tüketilen bir süt ürünüdür (Turgut, 2006). Ayrıca probiyotik bakterilerin canlılıklarını ve gelişimlerini olumsuz etkileyecek düşük pH'ya sahip olmaması, yapılan bazı çalışmalarda bakterilerin canlılık düzeylerinin yüksek oranda korunması gibi birtakım özellikler taşıması, dondurmayı probiyotik bakterilerin vücuda canlı olarak alımı için cazip hale getirmektedir (Kırmacı ve ark., 2014). Ancak dondurma işleminin canlı bakteri sayısında 0,5-1 log birimlik kayba neden olabileceği, depolama sırasındaki (6-12 aylık) sıcaklık dalgalanmalarının üründe buz kristalleri oluşturarak bakteri hücrelerinin canlılıklarında azalmalar meydana getirdiği de belirtilmektedir (Davidson ve ark., 2000). Aynı şekilde dondurma miksinin karıştırılması esnasında uygulanan mekanik etkinin bakteri hücrelerinde hasara neden olabileceği, dondurma karışımına istenen overrun değerini vermek amacıyla belli miktarda uygulanan havanın, üründeki oksijen düzeyini artırarak anaerobik ve mikroaerofilik karakterdeki probiyotik bakteriler üzerinde inhibe edici etki oluşturabileceği de dikkate alınması gereken bir husus olarak değerlendirilmektedir (Şener, 2009).

Tüm bunların yanında gıdanın işlenmesinden kaynaklanan engeller (yüksek sıcaklık, yüksek basınç, kurutma, dondurma, asidik veya alkali ortam), tüketiminden sonra metabolizmadan kaynaklanan engeller (sindirim sistemi enzimleri, yüksek asidik ortam ve safra tuzları) ve mikroorganizmanın kendisinden kaynaklanan engeller de (anaerobik gelişme koşulları ve zengin besin maddeleri gereksinimi, oksijen, sıcaklık, pH, inhibitörler ve rekabetçi mikroorganizmalardan kaynaklanan stres koşulları) probiyotik mikroorganizma içeren gıdaların üretimini kısıtlayan faktörler olarak karşımıza çıkmaktadır (Desmond ve ark., 2004).

Günümüzde probiyotik bakterilerin canlı kalmasının önündeki bu engelleri ortadan kaldırmak veya en aza indirmek amacıyla, uygun bakteri suşu seçimi, gıda üretim proseslerinin modifikasyonu, depolama koşullarının iyileştirilmesi ve kontrol edilmesi ile uygun ambalaj seçimi gibi bazı önlemler alınmakla birlikte (Ergin, 2013), son yıllarda yapılan çalışmalarda mikroenkapsülasyon tekniği, üzerinde durulan bir yöntem haline gelmiş ve büyük bir önem kazanmıştır.

Mikroenkapsülasyon, hücre hasarını ve hücre kaybını azaltmak amacıyla hücrelerin uygun bir taşıyıcı destek materyali içine hapsedilme işlemidir (Krasaekoopt ve ark., 2003). Amaç, mikroorganizmaların çevresinde çeşitli maddelerle koruyucu bir film tabakası oluşturarak olumsuz çevre koşullarına karşı canlılığının devam etmesini sağlamaktır (Çakır, 2006).

Mikroenkapsülasyon amacıyla birçok teknik kullanılmakla birlikte, günümüzde en çok araştırılan yöntem, kalsiyum-aljinat jel kapsülü oluşumu esasına dayalı ekstrüzyon kaplamadır (Çakır, 2006). Aljinatın gerek tek başına gerekse de diğer kaplama materyalleriyle bir arada kullanıldığı çeşitli enkapsülasyon uygulamalarında hücrelerin canlılıklarının serbest forma göre daha iyi korunduğu bildirilmiştir (Annan ve ark., 2008; Chandramouli ve ark., 2004; Guerin ve ark., 2003; Homayouni ve ark., 2008; Liserre ve ark., 2007; Karthikeyan ve ark., 2014; Kim ve ark., 2008; Mandal ve ark., 2006; Muthukumarasamy \& Holley, 2006; Ortakci ve ark., 2012; Ortakci ve Sert, 2012; Shafiei ve ark., 2012; Sheu ve ark., 1993; Tsen ve ark., 2007). Kalsiyum aljinat dışında jelatin, pektin, nişasta, kappa-karreganan, gellan gum, peyniraltı suyu gibi gıdaların bileşiminde güvenle kullanılabilen maddelerden de kaplama materyali olarak yararlanılabilmektedir (Çakır, 2006). 
Aljinat kapsüllerinin mikroenkapsülasyon uygulamalarında yaygın olarak kullanılmasında sahip olduğu bazı avantajlar etkilidir. Bunlar; kolayca bakteri hücrelerinin etrafında jel matriksi oluşturması, vücut için toksik özellik taşımaması, gıda için güvenilir ve biyolojik açıdan uyumlu olması, ucuz olması, iyi performans gösterebilmesi için ılımlı proses koşullarına (sıcaklık gibi) gerek duyması, kolay hazırlanabilir ve uygulanabilir olması, bağırsaklarda uygun bir şekilde çözünebilir ve tutuklanmış hücrelerin salınımına izin verebilir olmasıdır (Mortazavian ve ark., 2007).

Ekstrüksiyon yöntemi; hidrokolloid (aljinat gibi) kapsüllerin hazırlanmasında en eski ve en yaygın kullanılan bir yöntemdir (Krasaekoopt ve ark., 2003). Basit ve düşük maliyetli bir yöntem olmasının yanında genellikle bu yöntemde hücre yaralanması minimum düzeydedir ve probiyotik hücrelerin canlılığı nispeten yüksek oranda korunmaktadır. Boncuk büyüklüğü ve şekli, iğnenin çapı, aljinat çözeltisinin yoğunluğu ve serbest düşme mesafesine bağlı olarak değişmektedir. Aljinat konsantrasyonu ve dolayısıyla viskozite arttıkça boncukların boyutu azalmaktadır (Krasaekoopt ve ark., 2003; Mortazavian ve ark., 2007).

Bu çalışmada probiyotik Lb. acidophilus ATCC 4356 suşu, enjektör (şırınga) kullanılarak ekstrüzyon yöntemi ile kaplanmış ve kaplama materyali olarak sodyum aljinat kullanılmıştır. Ardından enkapsüle ve serbest kültürler dondurmaya ilave edilerek $-18^{\circ} \mathrm{C}$ 'deki depolama stabiliteleri araştırılmıştır.

\section{Gereç ve Yöntem}

\section{Gereç}

Dondurma: Bu çalışmada kullanılan dondurma, Atatürk Üniversitesi Ziraat Fakültesi Pilot Süt Fabrika’sından temin edilmiştir.

Probiyotik bakteri suşları: Bu çalışmada mikroenkapsülasyona tabi tutulacak probiyotik bakteri suşu olarak Lactobacillus acidophilus ATCC 4356 kullanılmıştır. Lactobacillus acidophilus ATCC (American Type Culture Collection-Amerikan Tipi Kültür Koleksiyonu) 4356 bakteri suşu Microbiologics firmasından orijinal paketi içinde liyofilize formda temin edilmiştir.

Besiyerleri, dilüsyon sıvıları ve çözeltiler: Çalışmada bakteri suşlarının aktifleştirilmesinde ve mikrobiyolojik sayımların gerçekleştirilmesinde MRS broth (Merck) besiyeri kullanılmıştır.

Mikrobiyolojik analizlerde dilüsyonların hazırlanmasında Tamponlanmış Peptonlu Su (Merck) kullanılmıştır.

Diğer kimyasal maddeler: Mikroorganizmaların kaplanmasında sodyum aljinat (Sigma), tampon çözelti hazırlanmasında $\mathrm{Na}_{2} \mathrm{HPO}_{4} \cdot 7 \mathrm{H}_{2} \mathrm{O}$ (Merck), $\mathrm{NaH}_{2} \mathrm{PO}_{4} \cdot \mathrm{H}_{2} \mathrm{O}$ (Merck) kullanılmıştır.

\section{Yöntem}

Deneme planı: Araştırma serbest ve enkapsüle $L b$. acidophilus ATCC 4356 içeren dondurma örneklerinden olmak üzere iki farklı muamele ve 0,30 , ve 90 günlük 3 farklı depolama süresi ile üç tekerrürlü olarak $2 \times 3 \times 3$ faktöriyel düzende tam şansa bağlı deneme planına göre kurulmuş ve yürütülmüştür.

\section{Probiyotik suş ve geliştirilmesi}

Kaplama işlemi uygulanacak Lb. acidophilus ATCC 4356 suşu öncelikle $9 \mathrm{ml}$ MRS Broth besiyerine inoküle edilmiş ve ardından $37^{\circ} \mathrm{C}$ 'de 48 saat anaerobik inkübasyona bırakılmıştır. İnkübasyon sonunda bu tüpten $2 \mathrm{~mL}$ alınarak yeni bir $9 \mathrm{~mL}$ 'lik MRS Broth besiyerine inoküle edilmiş ve $37^{\circ} \mathrm{C}$ 'de 24 saat anaerobik inkübasyona bırakılmıştır. Inkübasyondan çıkarılan tüp vortekslenerek 500 mL'lik MRS Broth besiyerine aktarılmış ve yeniden $37^{\circ} \mathrm{C}$ 'de 24 saat anaerobik ortamda inkübe edilmiştir. Elde edilen bakteri süspansiyonu 50 ml'lik 10 adet steril santrifüj tüplerine aktarılarak 5000 rpm'de $4^{\circ} \mathrm{C}$ 'de 15 dakika santrifüj edilmiştir. İçerisinde sadece pellet bulunan tüpler, her seferinde üzerine 2-3 mL steril peptonlu su ilave etmek suretiyle sırasıyla birbirine aktarılarak en nihayetinde toplamda $34 \mathrm{~mL}$ bakteri süspansiyonu elde edilmiştir. Bu süspansiyondan $1 \mathrm{ml}$ alınarak TPS içinde $10^{-6}$ düzeyine kadar seyreltildikten sonra her bir dilüsyondan yayma yöntemiyle MRS agara (Oxoid) ekim yapılmıştır. Anaerobik koşullarda $37^{\circ} \mathrm{C}$ 'de 48 saat inkübasyonun ardından Lb. acidophilus ATCC 4356 suşu $\sim 10^{9}$ kob/ml'ye çoğaltılmıştır. Böylece ileride yapılacak olan işlemlerde inkübasyon sonundaki sayıları belirlemek üzere başlangıçtaki yaklaşık m.o. sayısı tespit edilmiştir (Ortakcı, 2010).

Probiyotik bakterilerin aljinat içerisine mikroenkapsülasyonu Aljinat mikrokapsülleri, modifiye edilmiş kapsülleme yöntemi kullanılarak elde edilmiştir (Krasaekoopt ve ark., 2003; Ortakcı, 2010). Buna göre $20 \mathrm{~mL} 10^{9} \mathrm{kob} / \mathrm{ml}$ 'ye çoğaltılmış olan Lb. acidophilus ATCC 4356 kültür konsantratı, \%2,5 sodyum aljinat içeren $80 \mathrm{~mL}$ steril aljinat solüsyonuna manyetik karıştırıcı kullanılarak yaklaşık 10 dakika süreyle yavaş yavaş ilave edilmiş ve immobilizasyonu gerçekleştirilmiştir. Elde ettiğimiz aljinatbakteri süspansiyonu, aljinatın jel içerisinde küresel boncuk oluşturmasını sağlayan $500 \mathrm{~mL} 0.2 \mathrm{M} \mathrm{CaCl}_{2}$ çözeltisi içerisine, steril $21 \mathrm{G}$ şırınga yardımıyla damla damla aktarılarak ekstrüde edilmiştir. Damlacıkların $\mathrm{CaCl}_{2}$ çözeltisi içerisine damlatılmasıyla birlikte aljinat, çapraz iyonik bağlanma sonucu 3 boyutlu kafes yapı içerisinde hücreleri hapsederek enkapsülasyonu gerçekleştirmekte ve jel küreler (mikrokapsüller) oluşmaktadır (Karthikeyan ve ark., 2014; Krasaekoopt ve ark., 2003). Son olarak $\mathrm{CaCl}_{2}$ çözeltisi içerisindeki mikrokapsülleri elde etmek üzere Whatmann \# 4 filtre kâğıdı kullanmak suretiyle süzme işlemi gerçekleştirilmiştir. Filtre edilen mikrokapsüller aynı gün dondurmaya katılmak üzere $4^{\circ} \mathrm{C}$ 'de steril petri kutusunda muhafaza edilmiştir. Ekstrüzyon tekniği kullanılarak elde edilen kalsiyum aljinat mikrokapsülleri Şekil 1'de gösterilmiştir.

Mikrokapsüllerin boyutlarının belirlenmesi: Mikrokapsüllerin boyutlarının belirlenmesi amacıyla 25 mL'lik dereceli silindir

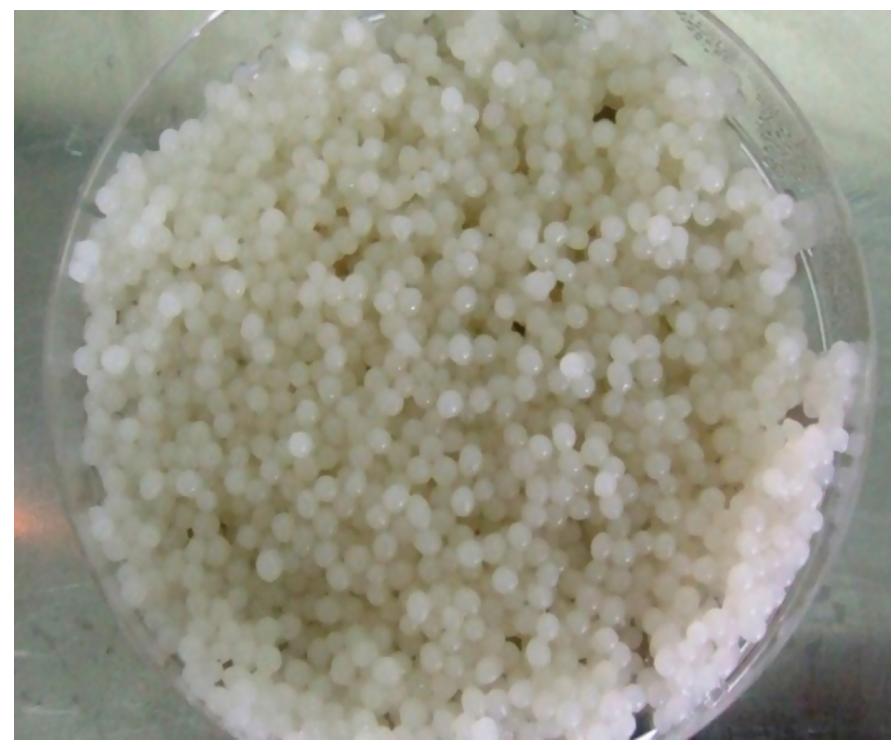

Şekil 1.

Kalsiyum-Aljinat Mikrokurelerinin görünümleri 
kullanılmıştır. 50 adet kapsül, içerisinde $10 \mathrm{~mL}$ saf su bulunan silindire ilave edilerek hacim artışı not edilmiş, daha sonra 1 adet kapsülün hacminden yola çıkılarak küre hacim formülünden çap hesaplanmıştır. Böylece bir kapsülün ortalama boyutu belirlenmiştir.

Mikrokapsül içerisindeki probiyotik bakteri düzeyinin belirlenmesi: Kuru formdaki aljinat mikrokapsüller içerisindeki bakteri düzeyini belirlemek amacıyla $1 \mathrm{~g}$ mikrokapsül $99 \mathrm{mLO}, 2 \mathrm{M}$ fosfat tamponu ( $\mathrm{pH}$ 7.0) içerisine aktarılmış ve 10 dakika süresince stomacher cihazında homojenize edilmiştir. Bunu takiben uygun seri dilüsyonlar hazırlanmış ve MRS agar besiyeri kullanılarak yayma plak yöntemi ile canlı hücre sayımları belirlenmiştir (Ortakcı, 2010). Sonuçların ortalamaları, numunenin gramı başına koloni oluşturan birimin logaritması alınarak (log kob/g) ifade edilmiştir.

Mikroenkapsüle ve serbest bakterileri içeren dondurmaların depolanması: Mikroenkapsüle bakteri içeren dondurmaların hazırlanmasında Atatürk Üniversitesi Ziraat Fakültesi Pilot Süt Fabrikasından temin edilen dondurma kullanılmıştır. 50 mL'lik steril plastik tüplere 18'er g konulan dondurmalar oda sıcaklığında 10 dakika bekletilerek kısmen erimeleri sağlanmış ve içerisine $10^{8}$ kob/g düzeyinde canlı kültür içeren kapsüllerden 2 g katılıp homojen bir karışım meydana getirilmiştir. Mikroenkapsüle bakterileri içeren dondurmalar 90 gün süreyle $-18^{\circ} \mathrm{C}$ 'de depolamaya tabi tutulmuş ve 0, 30, ve 90 gün sonunda $L b$. acidophilus ATCC 4356 sayımı gerçekleştirilmiştir.

Serbest bakteri içeren dondurmaların hazırlanmasında da yine 50 ml'lik steril plastik tüplere 9'ar g dondurma konulmuş ve oda sıcaklığında 10 dakika bekletmek suretiyle kısmen erimeleri sağlanarak üzerine $1 \mathrm{ml}$ bakteri süspansiyonundan ilave edilmiştir. Ardından 90 gün süreyle $-18^{\circ} \mathrm{C}$ 'de depolamaya tabi tutulmuş ve 0,30 , ve 90 gün sonunda Lb. acidophilus ATCC 4356 sayımı gerçekleştirilmiştir. Böylece $-18^{\circ} \mathrm{C}$ 'de muhafaza edilen dondurmalarda depolama periyodu boyunca serbest ve mikroenkapsüle bakterilerin canlııklarındaki değişimler tespit edilmeye çalışılmıştır.

Depolama periyodu boyunca dondurma örneklerinden $L$ b. acidophilus ATCC 4356'nın sayımı: Depolama boyunca örneklerdeki canlı bakteri düzeylerinde meydana gelebilecek değişimleri belirlemek amacıyla 0, 30, ve 90. günlerde mikrobiyolojik sayımlar gerçekleştirilmiştir. Buna göre hem serbest formdaki hem de enkapsüle formdaki probiyotik bakterileri içeren örneklerin 10${ }^{1}$ 'lik ilk dilüsyonları hazırlanarak stomacher cihazında homojenize edilmiş ve daha sonra uygun seri dilüsyonları hazırlanmıştır.

Son aşamada yayma plak yöntemiyle her bir dilüsyondan MRS agar (Oxoid) besiyeri kullanılarak anaerobik koşullarda $\left(37^{\circ} \mathrm{C}\right.$ 'de 48 saat) canlı bakteri sayımları gerçekleştirilmiştir.

\section{Dondurma örneklerinde duyusal analiz}

Dondurmalar, oda sıcaklığında 20 dakika bekletilerek kısmen erimeleri sağlanmış ve 25'er gramlık porsiyonlara bölünerek içerisine $10^{8} \mathrm{kob} / \mathrm{g}$ düzeyinde canlı kültür içeren kapsüllerden 1/100 oranında katılıp homojen bir karışım sağlanmıştır. Daha sonra 1 gün süreyle $-18^{\circ} \mathrm{C}$ 'de depolamaya tabi tutulmuş ve ardından duyusal analizleri yapılmıştır. Analizlerde kontrol olarak serbest mikroorganizma katılmış dondurma kullanılmıştır.

Duyusal analizlerin gerçekleştirilmesinde, Türk Standartları Enstitüsü “TS 4265 Süt Esaslı Dondurma” standardı esas alınarak hazırlanan duyusal değerlendirme puan cetveli kullanılmıştır. 10 farklı panelist tarafından gerçekleştirilen bu değerlendirmelerde renk, görünüş, yapı, kıvam, tat ve koku kriterleri dikkate alınmıştır.

\section{İstatistiksel analizler}

Araştırma sonuçlarının değerlendirilmesinde Statistical Package for the Social Sciences (SPSS Inc., Chicago, IL, USA) 17.0 istatistik paket programı kullanılmıştır. Varyanslar arasındaki farklılığın önem kontrolü One-way ANOVA varyans analizi kullanılarak saptanmış, önemli bulunan ana varyasyon kaynaklarına ait ortalamalar ise Tukey çoklu karşılaştırma testi ile karşılaştırılmıştır.

\section{Bulgular ve Tartışma}

\section{Mikrokapsüllerin Boyutlarının Belirlenmesi}

Lb. acidophilus ATCC 4356 suşunun \%2,5'lik sodyum aljinat ile kaplanmasında elde edilen kapsüllerin boyutlarının belirlenmesi amacıyla 50 adet kapsül, içerisinde $10 \mathrm{~mL}$ saf su bulunan 25 mL'lik dereceli silindire ilave edilmiş, sonuçta 0,5 mL'lik hacim artışı olmuştur. Buna göre 1 adet kapsülün yaklaşık hacmi 0,01 mL olarak tespit edilmiştir.

Kürenin hacmi $(V)=\frac{4}{3} \pi r^{3} 0,01=\frac{4}{3} \times 3,14 \times r^{3} r^{3}=0,00238$

$r=0,133 \mathrm{~cm} R=2 r \rightarrow R=2 \times 0,133=0,266 \mathrm{~cm}$

Yaklaşık $2660 \mu \mathrm{m}$ (2,66 mm) çap boyutuna sahip kapsül elde edilmiştir. Reid ve ark. (2005), peyniraltı suyu proteinlerini kaplama materyali olarak kullanarak ekstrüzyon yöntemiyle probiyotiklerin mikroenkapsülasyonunu gerçekleştirdikleri çalışmalarında, yaklaşık $3 \mathrm{~mm}$ boyutlarında boncuklar elde etmişlerdir. Bu açıdan değerlendirildiğinde, arzu edilen boyutta kapsül elde edildiğini söylemek mümkündür. Şüphesiz, kullanılan destek materyalinin çeşidi, konsantrasyonu, şırınga ve reaktörün birbirine olan uzaklığı ve şırınga başlığının çapı oluşan kürelerin boyutunu direkt olarak etkileyen en önemli parametrelerdir. Sheu ve ark. (1993), büyük kapsüllerin dondurmanın tekstüründe pürüzlülüğe ve kabalığa neden olabileceğini, çok küçük kapsüllerin de probiyotik bakterileri yeterli şekilde koruyamayabileceğini bildirmiştir.

\section{Serbest ve Enkapsüle Lb. acidophilus ATCC 4356'nın Depolama Süresince Dondurmadaki Gelişimi}

Depolama stabilitesinin belirlenmesinde serbest ve enkapsüle Lb. acidophilus ATCC 4356 içeren dondurma örnekleri $-18^{\circ} \mathrm{C}$ 'de depolanmıştır. 3 farklı depolama süresi ile yapılan sayımlarla, kaplama işleminin mikroorganizmanın canlılığı üzerine etkisi belirlenmiştir. Başlangıçta serbest ve enkapsüle $L b$. acidophilus ATCC 4356 sayıları sırasıyla 8,55 ve 8,32 log kob/g iken depolama sonunda sırasıyla 7,60 ve 7,44 log kob/g'a düştüğü gözlemlenmiştir.

Deneme dondurma örneklerine ait depolama periyodunda elde edilen Lb. acidophilus ATCC 4356 sayıları (log kob/g) Tablo 1'de, canlılık oranları Tablo 2'te verilmiştir.

Serbest ve enkapsüle Lb. acidophilus ATCC 4356 içeren dondurmalara ait depolama periyodunda Lb. acidophilus ATCC 4356 sayılarına ait varyans analiz sonuçları Tablo 3'te verilmiştir.

Tablonun bakteri satırındaki anlamlılık değeri $(P=, 718, P>, 05)$, bakterilerin enkapsüle edilip edilmemesiyle canlı m.o. oranı arasındaki ilişkinin istatistiksel olarak anlamlı olmadığını ortaya koymaktadır.

Tablonun depolama satırındaki anlamlılık değeri ise, serbest ve enkapsüle Lb. acidophilus ATCC 4356 içeren dondurmalarda, depolamanın bakterilerin canlıık oranları üzerine çok önemli etki ettiğini göstermektedir $(P<, 01)$. 
Bakteri*Depolama değerlerine baktığımızda, bakteri formunun ve depolama süresinin canlı m.o. oranı üzerindeki ortak etkisinin istatistiksel olarak anlamlı olmadığı görülmektedir $(P=, 949, P$ $>$,05). Bu bulgular ışığında serbest ve enkapsüle bakteri içeren dondurmaların canlı m.o. oranları, bakteri formuna bağlı olarak farklılık göstermezken, depolama süresine bağlı olarak farklılık göstermektedir denilebilir.

Deneme dondurmaların depolanması esnasında belirlenen serbest ve enkapsüle Lb. acidophilus ATCC 4356'nın canlılık oranlarına ait One-way ANOVA varyans analizi Tablo 4'te verilmiştir. Böylelikle farklı bakteri formlarına sahip dondurmaların canlı m.o. oranları arasında fark olup olmadığı belirlenmiştir.

Buna göre göre serbest Lb. acidophilus ATCC 4356 depolama periyodunda ortalama \%96,08 oranında canlılığını sürdürebilmişken, enkapsüle Lb. acidophilus ATCC 4356 ortalama \%96,34 oranında canlı kalabilmiştir.

Yukarıdaki tabloya bakıldığında, enkapsüle bakteri içeren dondurma örneklerindeki canlı m.o. oranlarının serbest bakteri içeren dondurma örneklerindeki canlı m.o. oranlarından çok az farkla fazla olduğu görülmektedir. Ancak bu farklılıkların rastlantısal mı; yoksa herhangi bir etki sonucu mu olup olmadığını belirleyebilmek için ANOVA tablosunu incelememiz gerekir (Tablo 5).

ANOVA tablosunun Anlamlılık (p) sütunundaki değerin 0,922 olduğu görülmektedir. Söz konusu değer 0,05'den büyük olduğu için serbest ve enkapsüle Lb. acidophilus ATCC 4356'nın 90 günlük depolamanın sonunda canlı kalabilme oranları arasında istatistiksel olarak anlamlı bir fark olmadığını söyleyebiliriz $(P>, 05)$.

Deneme dondurmalardan depolama periyodunda belirlenen canlı m.o. oranlarına ait ortalamaların One-way ANOVA varyans analizi Tablo 6'da, Tukey çoklu karşılaştırma test sonuçları ise Tablo 7'de verilmiştir. Böylelikle farklı depolama sürelerindeki dondurmaların canlı mikroorganizma oranları arasındaki farklılıklar değerlendirilmiştir.

Görüldüğü üzere her iki tip dondurma esas alındığında depolama süresine bağlı olarak canlı m.o. oranlarında bir azalma söz konusudur (Tablo 6). Bununla birlikte Tablo 7'deki anlamlılık sütunundaki değerlerden, O. gün ile 30. gün depolama süresinin canlı m.o.

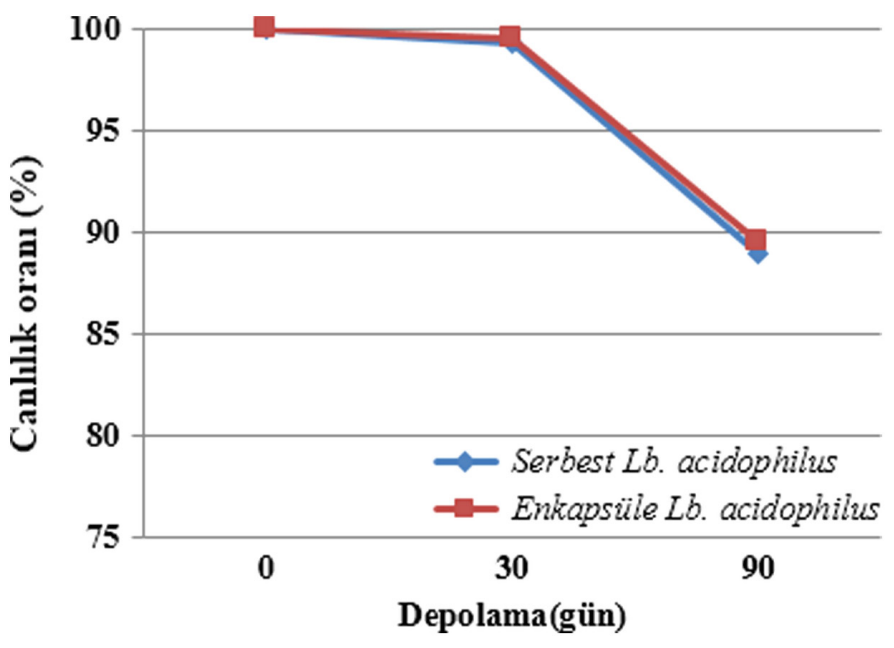

Şekil 2.

Deneme Dondurmalarda Lb. acidophilus ATCC 4356'nın Canlılık Oranı Üzerine Depolama SüresiX Serbest/Enkapsüle Form Interaksiyonunun Etkisi oranları arasındaki farkın istatistiksel olarak anlamlı olmadığı $(P$ $>$,05), 90. gündeki canlı m.o. oranlarındaki değişimin ise $P<, 05$ düzeyinde anlamlı olduğu anlaşılmaktadır.

Deneme dondurmalarda Lb. acidophilus ATCC 4356'nın canlılık oranı (\%) üzerine depolama süresi x serbest/enkapsüle form interaksiyonunun etkisi Şekil 2'de verilmiştir.

Sonuçların genel bir değerlendirmesi yapıldığında; soğuk depolamanın dondurma örneklerindeki canlı bakteri sayılarında azalmaya neden olduğu ve 3 aylık soğuk depolama boyunca mikroenkapsüle ve serbest formdaki bakterileri içeren dondurma örneklerindeki canlı bakteri düzeylerinde önemli bir değişiklik olduğu, buna karşılık serbest ve enkapsüle örnekler arasında önemli bir fark olmadığı gözlemlenmiştir. Benzer sonuçlar Homayouni ve ark. (2008), Jurkiewicz ve ark. (2011) ve Karthikeyan ve ark. (2014) tarafından da elde edilmiş, 90 günlük depolama süresi sonunda dondurmalardaki serbest ve enkapsüle Lactobacillus casei Lc-01, Lactobacillus acidophilus NCFM, Bifidobacterium lactis $\mathrm{BI}-\mathrm{O} 4$, Lb. acidophilus (LA-5) bakterilerinin canlılıklarında anlamlı bir farklılık gözlemlenmemiştir. Bununla birlikte Homayouni ve ark. (2008) ve Karthikeyan ve ark. (2014)'nın çalışmalarında, söz konusu enkapsüle mikroorganizmalar, 180 günlük depolama süresi sonunda serbest mikroorganizmalara göre çok daha yüksek oranda canlılıklarını sürdürmüşlerdir. Dolayısıyla mikroenkapsüllemenin etkisinin, 120 günden daha uzun bir depolama süresinin sonunda gerçekleştiğini söylemek mümkün olacaktır.

\section{Duyusal Analiz}

Serbest ve enkapsüle Lb. acidophilus ATCC 4356 içeren dondurmalara ait renk ve görünüş, yapı ve kıvam, tat ve koku ile toplam kabul edilebilirlik duyusal değerlendirme sonuçları Tablo 8'de verilmiştir. Tablolarda belirtilen puanlar, 10 farklı panelistin 3 tekerrürlü olarak gerçekleştirilen duyusal analizde 1-5 puan aralığında yapılan değerlendirmelerin ortalaması alınarak hesaplanmıştır.

Tablo 9'da da görüldüğü üzere, yapılan istatistiksel analiz sonucunda serbest ve enkapsüle $L b$. acidophilus ATCC 4356 içeren dondurma örneklerinin, yapı ve kıvam ile toplam kabul edilebilirlik özellikleri üzerinde önemli seviyede $(P<, 05)$ farklılık arz ettiği; renk ve görünüş ile tat ve koku parametreleri arasındaki farkın ise istatistiksel açıdan önemsiz olduğu bulunmuştur.

Deneme dondurma örneklerinin yapı ve kıvam özelliklerine ait duyusal değerlendirme puan ortalamalarının One-way ANOVA varyans analizi sonuçları Tablo 10'da verilmiştir.

Yapılan duyusal analiz sonuçlarına göre enkapsüle $L b$. acidophiIus ATCC 4356 içeren dondurma örnekleri yapı ve kıvam özellikleri bakımından genel olarak daha düşük puanlarla değerlendirilmiştir. Buna karşılık bazı panelistlerin enkapsüle bakteri içeren dondurma örneklerine ait yapı ve kıvam puanları "iyi” olarak değerlendirilen 4.0 ve üzerinde olmuştur (Tablo 11).

Deneme dondurma örneklerinin genel kabul edilebilirlik özelliklerine ait duyusal değerlendirme puan ortalamalarının One-way ANOVA varyans analizi sonuçları Tablo 12'de verilmiştir.

Yapılan duyusal analiz sonuçlarına göre, enkapsüle L. acidophiIUs ATCC 4356 içeren dondurma örnekleri, toplam kabul edilebilirlik özellikleri bakımından genel olarak daha düşük puanlarla değerlendirilmiştir (Tablo 13). İstatistiksel analiz sonucunda da dondurma örneklerinin toplam kabul edilebilirlik özellikleri 
Tablo 1.

Deneme Dondurma Örneklerine Ait Depolama Periyodunda Elde Edilen Lb. acidophilus ATCC 4356 Sayıları (log kob/g)

\begin{tabular}{|l|c|c|c|}
\hline \multirow{2}{*}{ Dondurma Örnekleri } & \multicolumn{3}{|c|}{ Depolama Süresi (Gün) } \\
\cline { 2 - 4 } & $\mathbf{0}$ & $\mathbf{3 0}$ & $\mathbf{9 0}$ \\
\hline Serbest & $8,55 \pm 0,083$ & $8,49 \pm 0,070$ & $7,60 \pm 0,285$ \\
\hline Mikroenkapsüle & $8,32 \pm 0,078$ & $8,28 \pm 0,072$ & $7,44 \pm 0,125$ \\
\hline
\end{tabular}

Tablo 2.

Deneme Dondurma Örneklerine Ait Depolama Periyodunda Elde Edilen Lb. acidophilus ATCC 4356 Oranları (\%)

\begin{tabular}{|l|c|c|c|}
\hline \multirow{2}{*}{ Dondurma Örnekleri } & \multicolumn{3}{|c|}{ Depolama Süresi (Gün) } \\
\cline { 2 - 4 } & $\mathbf{0}$ & $\mathbf{3 0}$ & $\mathbf{9 0}$ \\
\hline Serbest & $100,00 \pm 0,00$ & $99,33 \pm 0,74$ & $88,92 \pm 3,03$ \\
\hline Mikroenkapsüle & $100,00 \pm 0,00$ & $99,55 \pm 0,13$ & $89,46 \pm 1,74$ \\
\hline
\end{tabular}

Tablo 3.

Serbest ve Enkapsüle Edilmiş Bakterileri Içeren Dondurmaların Depolanmasında Lb. acidophilus ATCC 4356'nın Canlı Kalma Oranlarına (\%) Ait Varyans Analiz Sonuçları

\begin{tabular}{|c|c|c|c|c|}
\hline \multirow{2}{*}{$\begin{array}{l}\text { Ana varyasyon } \\
\text { Kaynakları }\end{array}$} & \multirow[b]{2}{*}{ SD } & \multicolumn{3}{|c|}{ Lb. acidophilus ATCC 4356 oranı (\%) } \\
\hline & & KO & $\mathbf{F}$ & Anlamlılık \\
\hline Bakteri $(\mathrm{B})^{* * *}$ & 1 & 0,291 & 0,136 & 0,718 \\
\hline Depolama (D) & 2 & 222,151 & 103,915 & $0,00^{* *}$ \\
\hline $\begin{array}{l}\text { Bakteri*Depolama } \\
\text { BxD }\end{array}$ & 2 & 0,112 & 0,052 & 0,949 \\
\hline Hata & 12 & 0,589 & & \\
\hline
\end{tabular}

Tablo 4.

Dondurmaların Depolanmaları Sırasında Belirlenen Serbest ve Enkapsüle Lb. acidophilus ATCC 4356'nın Canlıık Oranlarına (\%) Ait Ortalamaların One-Way ANOVA Varyans Analizi

\begin{tabular}{|l|c|c|c|}
\hline \multirow{2}{*}{ Mikroorganizma } & & \multicolumn{2}{|c|}{$\begin{array}{c}\text { Lb. acidophilus ATCC 4356 canlı kalma } \\
\text { oranı (\%) }\end{array}$} \\
\cline { 3 - 4 } & N & Ortalama & Standart Sapma \\
\hline Serbest & 9 & 96,08 & $5,60 \mathrm{a}$ \\
\hline Enkapsüle & 9 & 96,34 & $5,23 \mathrm{a}$ \\
\hline
\end{tabular}

Farklı harfle işaretlenmiş ortalamalar istatistiki olarak birbirinden farkıdır $(P<, 05)$

Tablo 5.

Serbest ve Enkapsüle Lb. acidophilus ATCC 4356'nın Canlı Kalabilme Oranları Arasındaki One-Way ANOVA Varyans Analizi

\begin{tabular}{|l|c|c|c|c|}
\hline $\begin{array}{l}\text { Lb. acidophilus ATCC } \mathbf{4 3 5 6} \text { canlı } \\
\text { kalma oranı (\%) }\end{array}$ & SD & KO & F & Anlamlılık \\
\hline Gruplar arasında & 1 & 0,291 & 0,10 & 0,922 \\
\hline Gruplar içinde & 16 & 29,386 & & \\
\hline Toplam & 17 & & & \\
\hline
\end{tabular}

üzerinde örnekler arasındaki farkın, önemli olduğu bulunmuştur $(P<, 05)$.

Enkapsüle L. acidophilus ATCC 4356'nın kullanıldı̆ı dondurma örneklerine eklenen kapsüllerin duyusal yönden etkisini
Tablo 6.

Depolama Periyodunda Belirlenen Canlı Lb. acidophilus ATCC 4356

Oranlarına Ait Ortalamaların One-Way ANOVA Varyans Analizi

\begin{tabular}{|c|c|c|c|}
\hline \multirow[b]{2}{*}{ Depolama } & \multirow[b]{2}{*}{$\mathbf{N}$} & \multicolumn{2}{|c|}{ Lb. acidophilus ATCC 4356 canlı kalma oranı (\%) } \\
\hline & & Ortalama & Standart Sapma \\
\hline O. gün & 6 & 100 & $0,00 \mathrm{a}$ \\
\hline 30. gün & 6 & 99,44 & $0,49 a$ \\
\hline 90. gün & 6 & 89,19 & $2,23 b$ \\
\hline
\end{tabular}

Tablo 7.

Depolama Periyodunda Belirlenen Canlı Lb. acidophilus ATCC 4356 Oranlarına Ait Ortalamaların Tukey Çoklu Karşılaştırma Test Sonuçları

\begin{tabular}{|c|c|c|c|c|}
\hline \multirow{2}{*}{\multicolumn{2}{|c|}{ depolama (gün) }} & \multicolumn{3}{|c|}{ Subset for alpha $=0.05$} \\
\hline & & \multicolumn{2}{|l|}{1} & 2 \\
\hline \multicolumn{2}{|l|}{90} & \multicolumn{2}{|c|}{89,1950} & \\
\hline \multicolumn{2}{|l|}{30} & & & 99,4467 \\
\hline \multicolumn{2}{|l|}{0} & & & 100,0000 \\
\hline \multicolumn{2}{|l|}{ Anlamlılık } & \multicolumn{2}{|l|}{1,000} &, 752 \\
\hline $\begin{array}{l}\text { (I) depolama } \\
\text { (gün) }\end{array}$ & $\begin{array}{c}\text { (J) depolan } \\
\text { (gün) }\end{array}$ & $\begin{array}{c}\text { Ortalamalar } \\
\text { arasındaki } \\
\text { fark (I-J) }\end{array}$ & $\begin{array}{c}\text { Standart } \\
\text { hata }\end{array}$ & Anlamlılık \\
\hline \multirow[t]{2}{*}{0} & 30 &, 55333 &, 76259 &, 752 \\
\hline & 90 & $10,80500^{*}$ & ,76259 &, 000 \\
\hline \multirow[t]{2}{*}{30} & 0 &,- 55333 & ,76259 &, 752 \\
\hline & 90 & $10,25167^{*}$ & ,76259 &, 000 \\
\hline \multirow[t]{2}{*}{90} & 0 & $-10,80500^{*}$ & ,76259 &, 000 \\
\hline & 30 & $-10,25167^{*}$ & ,76259 &, 000 \\
\hline
\end{tabular}

değerlendirmek amacıyla, panelistlerden özellikle tat ve koku ile yapı ve kıvam değerlendirmeleri sırasında dondurma örneklerinin ağızda herhangi bir pürüzlü yapı veya olumsuz bir his uyandırıp uyandırmadığına dikkat etmeleri istenmiştir. Yapılan duyusal değerlendirmelerde bazı panelistler tarafından düşülen özel notlarda, çeşitli dondurma örnekleri için "tekstürel yapısı, bilinen dondurma özelliğinde değil", "homojen olmayan bir yapı", "belirgin bir boncuğumsu kümelenme", "iyi erimemiş nişasta benzeri bir yapı" ifadeleri yer almıştır. Bu bağlamda panelistlerin, enkapsüle probiyotik bakteri ilave edilen dondurmaları, geleneksel dondurma tüketim alışkanlıklarından farklı olarak değerlendirdiği söylenebilir. Bazı örneklerde homojen olmayan bir yapıdan söz edilmesini, kapsüllerin dondurma içerisinde iyi bir şekilde karışmaması ve bunun sonucunda belli bir bölgede kapsüllerin toplanması ile açıklamak mümkündür. Bu durum, söz konusu ürünlerde yapı ve tekstürün damak tadına uygun şekilde geliştirilmesi gerektiği sonucunu ortaya çıkarmıştır. Öte yandan kapsüller dondurmalara ilave edilmeden önce bir süre saf suda bekletilmesine rağmen, kapsüllerin eldesinde $\mathrm{CaCl}_{2}$ çözeltisi kullanıldığından dolayı çok hafif derecede bir tuzluluk tadına sahip olduğu da ifade edilmiştir. Kapsüllerin ağızda meydana getirdiği "yabancı madde" hissi dışında renk, görünüş ve koku açısından herhangi bir olumsuzluk ifade edilmemiş; geleneksel dondurma tüketim alışkanlıklarından farklı olarak kapsüllerin 
Tablo 8.

Serbest ve Enkapsüle Lb. acidophilus ATCC 4356 içeren Dondurmalara Ait Duyusal Analiz Sonuçları

\begin{tabular}{|l|c|c|c|c|}
\hline Dondurma Örnekleri & Renk ve Görünüş & Yapı ve Kıvam & Tat ve Koku & Toplam Kabul Edilebilirlik \\
\hline Enkapsüle & $4,06 \pm 0,82$ & $3,63 \pm 0,96$ & $3,97 \pm 0,80$ & $3,72 \pm 0,85$ \\
\hline Serbest & $4,43 \pm 0,70$ & $4,11 \pm 0,71$ & $4,24 \pm 0,68$ & $4,22 \pm 0,62$ \\
\hline
\end{tabular}

\begin{tabular}{|c|c|c|c|c|c|c|c|c|}
\hline \multirow[b]{2}{*}{ Varyasyon Kaynakları } & \multicolumn{4}{|c|}{ Renk ve Görünüş } & \multicolumn{4}{|c|}{ Yapı ve Kıvam } \\
\hline & SD & KO & $\mathbf{F}$ & Anlamlılık & SD & KO & $F$ & Anlamlılık \\
\hline Dondurma Örnekleri & 1 & 2,017 & 3,417 & 0,070 & 1 & 3,408 & 4,732 & $0,034^{*}$ \\
\hline \multirow[t]{2}{*}{ Varyasyon Kaynakları } & Tat ve Koku & & & & \multicolumn{4}{|c|}{ Toplam Kabul Edilebilirlik } \\
\hline & SD & $\mathrm{KO}$ & $\mathrm{F}$ & Anlamlılık & SD & $\mathrm{KO}$ & $\mathrm{F}$ & Anlamlılık \\
\hline
\end{tabular}

\begin{tabular}{|l|c|c|c|}
\hline $\begin{array}{l}\text { Tablo 10. } \\
\text { Deneme Dondurma Örneklerinin Yapı ve Kıvam Özelliklerine Ait Duyusal Değerlendirme Puan Ortalamalarının One-Way ANOVA Varyans Analizi Sonuçları }\end{array}$ \\
\hline \multirow{2}{*}{ Dondurma örnekleri } & N & Ortalama & Yapım \\
\hline Serbest & 30 & 4,11 & $0,71 \mathrm{a}$ \\
\hline Enkapsüle & 30 & 3,63 & $0,96 \mathrm{~b}$ \\
\hline Farklı harfle işaretlenmiş ortalamalar istatistiki olarak birbirinden farklıdır $(P<, 05)$. & \\
\hline
\end{tabular}

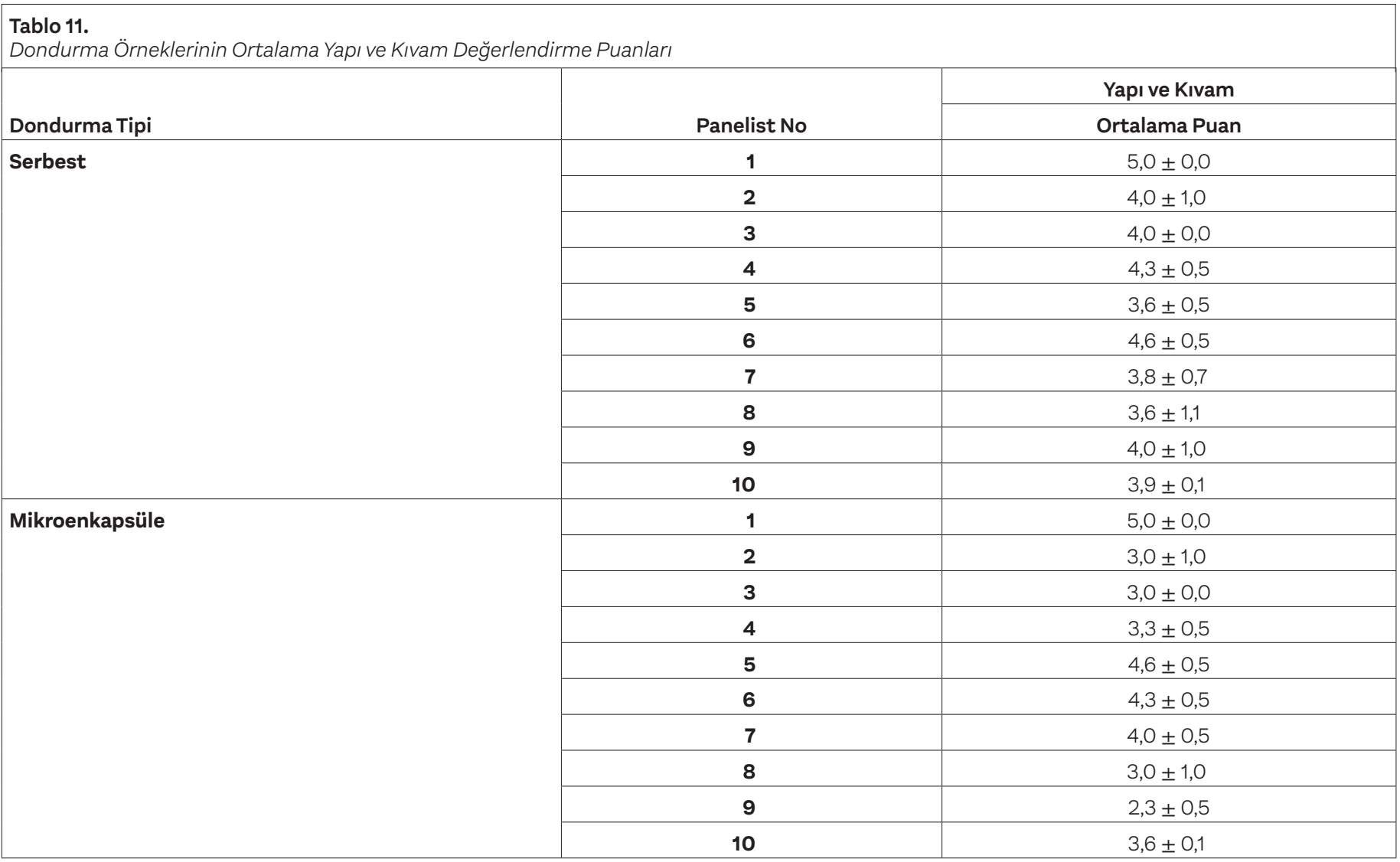


Tablo 12.

Deneme Dondurma Örneklerinin Toplam Kabul Edilebilirlik Özelliklerine Ait Duyusal Değerlendirme Puan Ortalamalarının One-Way ANOVA Varyans Analizi Sonuçları

\begin{tabular}{|l|c|c|c|}
\hline \multirow{2}{*}{ Dondurma örnekleri } & N & Ortalama & Toplam Kabul Edilebilirlik \\
\cline { 3 - 4 } Serbest & 30 & 4,22 & Standart Sapma \\
\hline Enkapsüle & 30 & 3,72 & $0,62 \mathrm{a}$ \\
\hline Farklı harfle işaretlenmiş ortalamalar istatistiki olarak birbirinden farklıdır $(P<, 05)$. & $0,85 \mathrm{~b}$ \\
\hline
\end{tabular}

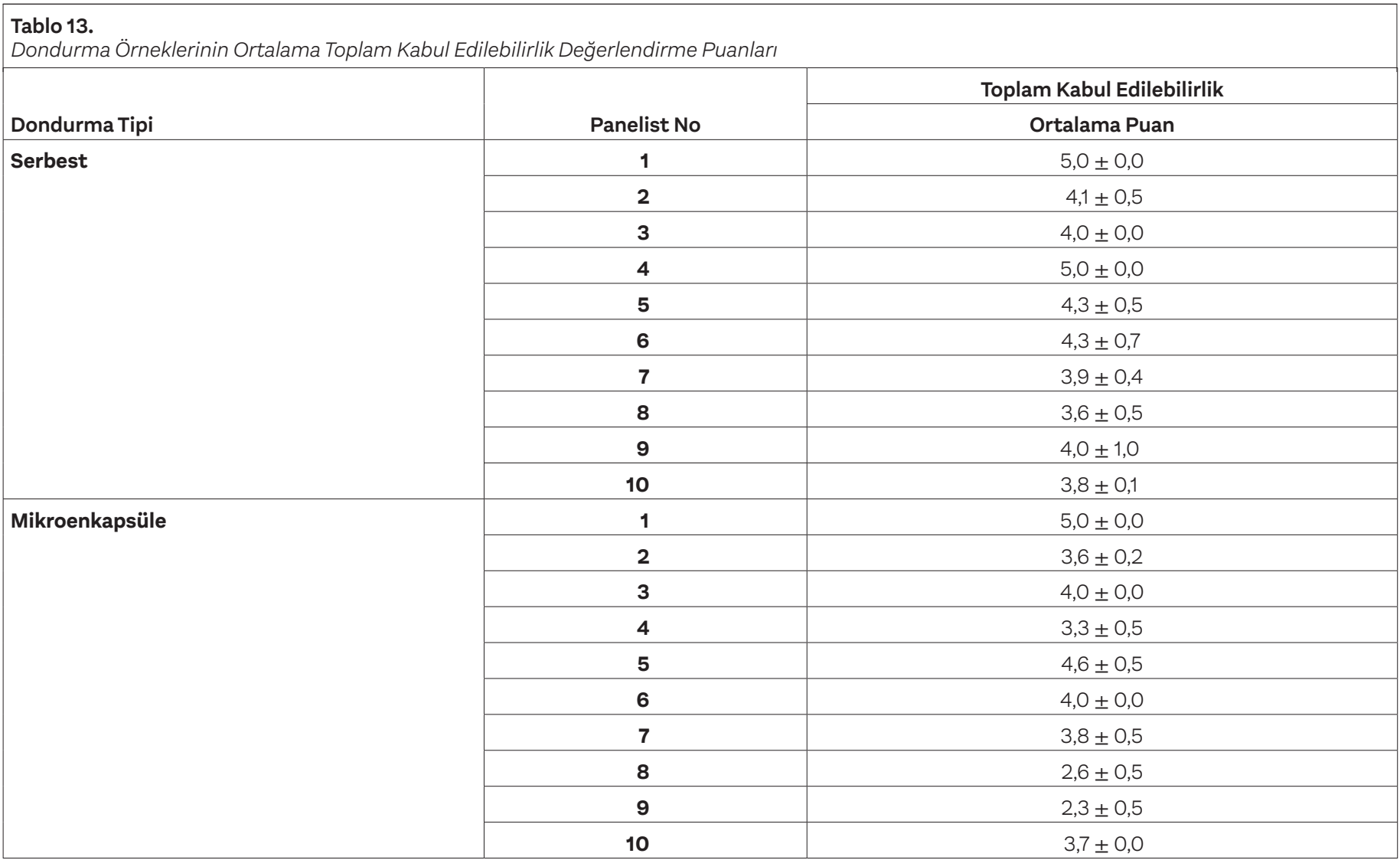

ağızda meydana getirdiği "yabancı madde" hissi dolayısıyla toplam kabul edilebilirliği düşük kalmıştır. Tüm bunlara karşılık, bazı panelistler tarafından dondurma içerisindeki bu kapsüller ilgi çekici bulunarak ağızda güzel bir his uyandırdığı ifade edilmiş ve toplam kabul edilebilirlik puanlamaları "iyi-tüketebilirim" olarak değerlendirilen 4.0 ve üzerinde olmuştur. Buna ilaveten kapsüllerin, çikolatalı veya farklı meyve aromalı soslarla kaplanmasıyla daha cezbedici bir görünüm oluşabileceği şeklinde fikirler de ileri sürülmüştür.

\section{Sonuç ve Öneriler}

Bu çalışmada; destek materyali olarak aljinat kullanılarak gerçekleştirilen mikroenkapsülasyon işleminin, probiyotik Lactobacillus acidophilus ATCC 4356 suşunun soğuk depolama sıcaklıklarına direnç özellikleri üzerine etkileri ve mikroenkapsüle probiyotik bakterilerin dondurma üretiminde kullanılabilirliği değerlendirilmeye çalışılmıştır.

Çalışma kapsamında, serbest ve enkapsüle Lb. acidophilus ATCC 4356 probiyotik bakteri suşu içeren dondurmaların soğuk depolama süresince canlı bakteri sayılarında anlamlı bir azalma belirlenmiş, ancak örnekler arasında önemli bir fark olmadığı gözlemlenmiştir. Hem serbest hem de enkapsüle Lb. acidophilus ATCC 4356 probiyotik bakteri suşunun, 90 günlük depolama süresi sonunda yaklaşık \%89 oranında canlılığını sürdürebilmesi, enkapsülasyon işleminin bakteriye ilave bir koruyucu etki sağlamadığı sonucunu ortaya çıkarmıştır. Örnekler arasında önemli bir farkın olmaması; gerek probiyotik Lb. acidophilus ATCC 4356 bakteri suşunun karakteristik özelliği olarak soğuğa karşı direnç göstermesi, gerekse de dondurmanın süt proteinleri $(\% 3,4)$, yağ $(\% 6,7)$ ve laktoz gibi süt bileşenlerini yoğun şekilde içermesi ve bu sayede probiyotik bakterileri koruması hatta çevreleyerek bir nevi kapsüllemesi neticesinde gerçekleşebileceği, buna ilave olarak pH değerinin probiyotik mikroorganizmaların yaşaması için uygun olmasından ( $\mathrm{pH}$ : 5.5-6.5) kaynaklandığı şeklinde yorumlanmıştır. Bu bağlamda gelecekte yapılacak çalışmalarda hayvan modelleri kullanımının yanı sıra başlangıç hücre sayıları, boncuk büyüklüğü, kaplama materyali seçimi ve konsantrasyonu ile taşıyıcı gıda maddesi seçimi gibi diğer parametreler incelenerek bağırsak bakterileri üzerinde mikrokapsüllemenin etkisini izlemek gerekmektedir. 
Öte yandan dondurmaların 90 günlük depolama periyodu boyunca, serbest ve enkapsüle Lb. acidophilus ATCC 4356 sayılarının $10^{7} \mathrm{kob} / \mathrm{g}^{\prime} ı n$ altına düşmemiş olması son üründe probiyotiklerin arzu edilen düzeyde canlılığını koruduğunu, dolayısıyla bakterinin terapotik ve koruyucu özelliklerini göstermesi açısından dondurmanın iyi bir probiyotik süt ürünü olarak kullanılabileceğini göstermiştir.

Panelistlere duyusal muayene öncesinde kapsüllerin içeriği hakkında bilgi verilmesi, dondurmalar üzerinde ilk gözlem esnasında oluşabilecek olumsuz izlenimi kırmış, bilinçli tüketime bağlı olarak kabul edilebilirlik artmıştır. Hayatımızın her anında bakterilerle iç içe yaşamamıza karşın, herhangi bir üründe -yararlı dahi olsa- bakterilerin kapsüller içerisine hapsedilmiş olması ve bu kapsüllerin net olarak görülmesi, tüketicilerde ister istemez bir çekince oluşturmuştur. Dolayısıyla bundan sonra yapılacak başka çalısmalarla probiyotik kültürlerle desteklenen dondurmalar ile ilgili eğitici kampanyaların düzenlenmesi ve tüketicilere bu ürünlerin yararını benimsetecek çalışmalara ağırlık verilmesi gerekmektedir. Bu manada gıda endüstrisinde bu amaca yönelik projeler yapılıp uygulama alanları oluşturularak laboratuvar çalışması halindeki birçok çalışmanın pratikte uygulanabilme imkânı sağlanmalıdır.

Etik Komite Onayı: N/A.

Hakem Değerlendirmesi: Dış Bağımsız.

Yazar Katkıları: Fikir - S.S., F.O., S.Sert.; Tasarım - S.S., F.O., S.Sert.; Denetleme - S.S., F.O.; Kaynaklar - S.S., F.O.; Malzemeler - S.S.; Veri Toplanması ve İşlenmesi - S.S.; Analiz ve Yorum - S.S., F.O.; Literatür Taraması - S.S.; Yazıyı Yazan - S.S.; Eleştirel İnceleme - S.S., F.O.

Çıkar Çatışması: Yazarlar çıkar çatışması bildirmemişlerdir.

Finansal Destek: Yazarlar bu çalışma icin finansal destek almadıklarını beyan etmişlerdir.

\section{Ethics Committee Approval: N/A.}

Peer-review: Externally peer reviewed.

Author Contributions: Concept - S.S., F.O., S.Sert.; Design - S.S., F.O., S.Sert.; Supervision - S.S., F.O.; Resources - S.S., F.O.; Materials - S.S.; Data Collection and/ or Processing - S.S.; Analysis and/ or Interpretation S.S., F.O.; Literature Search - S.S.; Writing Manuscript - S.S.; Critical Review - S.S., F.O.

Conflict of Interest: The authors declared that they have no conflict of interest.

Financial Disclosure: The authors declared that this study has received no financial support.

\section{Kaynaklar}

Annan, N. T., Borza, A. D., \& Hansen, L. T. (2008). Encapsulation in alginatecoated gelatin microspheres improves survival of the probiotic Bifidobacterium adolescentis 15703T during exposure to simulated gastro-intestinal conditions. Food Research International, 41(2), 184-193. [CrossRef]

Bilginer, H., \& Çetin, B. (2019). Probiyotiklerve Belirlenmelerinde Kullanılan in vitro Testler. Atatürk Üniversitesi Ziraat Fakültesi Dergisi, 50(3), 312-325. [CrossRef]

Çakır, İ. (2006). Mikroenkapsülasyon Tekniğinin Probiyotik Gıda Üretiminde Kullanımı. Türkiye 9. Bolu: Gıda Kongresi, 24-26 Mayıs, Poster Bildiriler Kongre Kitabı, 693-696.

Chandramouli, V., Kailasapathy, K., Peiris, P., \& Jones, M. (2004). An improved method of microencapsulation and its evaluation to protect Lactobacillus spp. in simulated gastric conditions. Journal of Microbiological Methods, 56(1), 27-35. [CrossRef]
Davidson, R. H., Duncan, S. E., Hackney, C. R., Eigel, W. N., \& Boling, J. W. (2000). Probiotic culture survival and implications in fermented frozen yoğurt characteristics. Journal of Dairy Science, 83(4), 666-673. [CrossRef]

Desmond, C., Fitzgerald, G. F., Stanton, C., \& Ross, R. P. (2004). Improved stress tolerance of GroESL-overproducing Lactococcus lactis and probiotic Lactobacillus paracasei, NFBC338. Applied and Environmental Microbiology, 70(10), 5929-5936. [CrossRef]

Donkor, O. N. (2007). Influence of probiotic organisms on release of bioactive compounds in yoghurt and soy yoghurt (PhD thesis). Victoria University, School of Molecular Sciences, Faculty of Health, Engineering and Science, UK.

Ergin, F. (2013). Farklı sıcaklık-süre kombinasyonlarında ısıl strese maruz bırakılan L. acidophilus'un dondurma üretiminde kullanımının araştırılması (s. 72). (Yüksek Lisans Tezi). Akdeniz Üniversitesi Fen Bilimleri Enstitüsü, Gıda Mühendisliği Ana Bilim Dalı, Antalya.

FAO / WHO, (2002). Guidelines for the evaluationof probiotics in food. Food and Agriculture Organization of the United Nations and World Health Organization Working Group Report. https://www.who.int/ foodsafety/fs_management/en/probiotic_guidelines.pdf.

Guérin, D., Vuillemard, J. C., \& Subirade, M. (2003). Protection of bifidobacteria encapsulated in polysaccaharide-protein gel beads against gastric juice and bile. Journal of Food Protection, 66(11), 2076-2084. [CrossRef]

Homayouni, A., Azizi, A., Ehsani, M. R., Yarmand, M. S., \& Razavi, S. H. (2008). Effect of microencapsulation and resistant starch on the probiotic survival and sensory properties of symbiotic ice-cream. Food Chemistry, 111(1), 50-55. [CrossRef]

Jurkiewicz, C., Boscarioli, M. P. M., Ferreira, R. G., Ribeiro, E. P., Prieto, W. H., \& Kunigk, L. (2011). Microencapsulation of probiotic bacteria with alginate and prebiotic and evaluation of survival in ice cream. São Caetano do Sul, Brazil: Maua Institute of Technology.

Kaleli, i. (2007). Probiyotiklerin etki Mekanizması. ANKEM Dergisi, 21, 238-242.

Karthikeyan, N., Elango, A., Kumaresan, G., Gopalakrishnamurty, T. R., \& Raghunath, B. V. (2014). Enhancement of probiotic viability in ice cream by microencapsulation. International Journal of Science Environmental and Technology, 3(1), 339-347.

Kim, S., Cho, S. Y., Kim, S. H., Song, O., Shin, I., Cha, D. S., \& Park, H. J. (2008). Effect of microencapsulation on viability and other characteristics in Lactobacillus acidophilus ATCC 43121. LWT - Food Science and Technology, 41(3), 493-500. [CrossRef]

Kırmacı, H. A., Hakan, K., \& Atasoy, A. F. (2014). Farklı Oranlarda Prebiyotik Lif İçeren Stevia Özü İlavesinin Probiyotik Dondurmanın Kalite Özellikleri etkisi. Harran Tarım ve Gıda Bilimleri Dergisi, 18(3), 48-59.

Krasaekoopt, W., Bhandari, B., \& Deeth, H. (2003). Evaluation of encapsulation techniques of probiotics for yoghurt. International Dairy Journal, 13(1), 3-13. [CrossRef]

Liserre, A. M., Ré, M. I., \& Franco, B. D. G. M. (2007) Microencapsulation of Bifidobacterium animalis subsp. lactis in Modified Alginate-chitosan Beads and Evaluation of Survival in simulated gastrointestinal conditions. Food Biotechnology, 21(1), 1-16. [CrossRef]

Mandal, S., Puniya, A. K., \& Singh, K. (2006). Effect of alginate concentrations on survival of microencapsulated Lactobacillus casei NCDC298. International Dairy Journal, 16(10), 1190-1195. [CrossRef]

Mortazavian, A., Razavi, S. H., Ehsani, M. R., \& Sohrabvandi, S. (2007). Principles and methods of microencapsulation of probiotic microorganisms. Iranian Journal of Biotechnology, 5(1), 1-18.

Muthukumarasamy, P., \& Holley, R. A. (2006). Microbiological and sensory quality of dry fermented sausages containing alginate-microencapsulated Lactobacillus reuteri. International Journal of Food Microbiology, 111(2), 164-169. [CrossRef]

Ortakcı, F. (2010). Probiyotik Bakterilerin Mikroenkapsülasyonla Sağlığa Yararlı Etkilerinin Artırılması (s. 50). (Yüksek Lisans Tezi). Yüksek Lisans Tezi Atatürk Üniversitesi Fen Bilimleri Enstitüsü. Gıda Mühendisliği Ana Bilim Dalı, Erzurum. 
Ortakci, F., Broadbent, J. R., McManus, W. R., \& McMahon, D. J. (2012). Survival of microencapsulated probiotic Lactobacillus paracasei LBC-1e during manufacture of Mozzarella cheese and simulated gastric digestion. Journal of Dairy Science, 95(11), 6274-6281. [CrossRef]

Ortakci, F., \& Sert, S. (2012). Stability of free and encapsulated Lactobacillus acidophilus ATCC 4356 in yogurt and in an artificial human gastric digestion system. Journal of Dairy Science, 95(12), 6918-6925. [CrossRef]

Özden, A. (2008). Inflamatuvar Barsak Hastalığında Probiyotiklerin yeri. Güncel Gastroenteroloji, 12(2), 121-127.

Reid, A. A., Vuillemard, J. C., Britten, M., Arcand, Y., Farnworth, E., \& Champagne, C. P. (2005). Microentrapment of probiotic bacteria in a Ca2induced whey protein gel and effects on their viability in a dynamic gastro-intestinal model. Journal of Microencapsulation, 22(6), 603-619.

Sanders, M. E., \& Klaenhammer, T. R. (2001). Invited Review: The scientific basis of Lactobacillus acidophilus NCFM Functionality as a probiotic. Journal of Dairy Science, 84(2), 319-331. [CrossRef]
Şener, A. (2009). Serbest ve Mikroenkapsüle Probiyotik Bakterilerin Ticari Dondurma Üretiminde Kullanılabilirliği Üzerine Bir Araştırma (s. 139). (Doktora Tezi). Hacettepe Üniversitesi Fen Bilimleri Enstitüsü Gıda Mühendisliği Anabilim Dalı, Ankara.

Shafiei, Y., Razavilar, V., Javadi, A., \& Mirzaei, H. (2012). Survivability of free and microencapsulated Lactobacillus plantarum with alginate and resistant starch in simulated gastrointestinal conditions. Journal of Food, Agriculture and Environment, 10(3-4), 207-212.

Sheu, T. Y., Marshall, R. T., \& Heymann, H. (1993). Improving survival of culture bacteria in frozen desserts by microentrapment. Journal of Dairy Science, 76(7), 1902-1907. [CrossRef]

Tsen, J. H., Huang, H. Y., Lin, Y. P., \& King, V. A. (2007). Freezing resistance improvement of Lactobacillus reuteriby using cell immobilization. Journal of Microbiological Methods, 70(3), 561-564. [CrossRef]

Turgut, T. (2006). Bazı Probiyotik Bakterilerin Dondurma Üretiminde Kullanım Imkanları (s. 168). (Doktora Tezi). Atatürk Üniversitesi Fen Bilimleri Ensttitüsü Gıda Mühendisliği Anabilim Dalı, Erzurum.

Ünal, E., \& Erginkaya, Z. (2010). Probiyotik Mikroorganizmaların Mikroenkapsülasyonu, Gıda Dergisi, 35(4), 297-304. 